\title{
7. GEOPHYSICAL LOGGING IN DEEP SEA DRILLING PROJECT HOLE 417D ${ }^{1}$
}

\author{
Matthew H. Salisbury, Deep Sea Drilling Project and Geological Research Division, Scripps Institution of Oceanography, \\ University of California, La Jolla, California \\ Thomas W. Donnelly, Department of Geology, State University of New York, Binghamton, New York \\ and \\ Jean Francheteau, Centre Océanologique de Bretagne, 29273 Brest Cedex, France
}

\section{INTRODUCTION}

During the past five years, several major attempts have been made to drill deep into the oceanic basement in an effort to determine the petrology and geophysical nature of the oceanic crust. Although significant basement penetration at several sites in the Atlantic (Table 1) has provided knowledge of the petrology of at least the upper levels of the crust, low core recovery has prevented accurate reconstruction of its geophysical behavior.

Recently, two attempts have been made to measure the physical properties of the oceanic basement directly by means of downhole geophysical logging. The first of these attempts (Kirkpatrick, 1979) was conducted in Hole 396B in $10-\mathrm{m} . \mathrm{y}$.-old crust at $23^{\circ} \mathrm{N}$ along the Mid-Atlantic Ridge. Although the operating conditions were not ideal (the density and porosity tools could not be pressed against the side of the hole), the experiment nonetheless clearly demonstrated that in-situ compressional wave velocities in young crust are consistent with those of Layer 2A (Houtz and Ewing, 1976) and that the porosity and fluid permeability of the uppermost basement are extremely high due, presumably, to the presence of numerous cracks and interpillow voids.

The second basement logging experiment was conducted in Hole 417D in 106-m.y.-old crust at the southern end of the Bermuda Rise at a water depth of 5479 meters (Figure 1). As can be seen in Figure 2, the drilled section in Hole 417 D consists of 343 meters of unconsolidated to semiconsolidated clay, claystone, and chalk of early Aptian to Recent age underlain by 366 meters of pillow basalt, breccia, and massive basalt of which 263 meters were recovered for a basement recovery of 72 per cent (Site 417 Report, this volume). Since the uppermost sediments were unstable, the hole was cased by drill pipe to a depth of 114 meters subbottom (later extended to $144 \mathrm{~m}$ ) to prevent caving. The open hole below the pipe was then logged in four stages to an obstruction in the basement at 445 meters sub-bottom using Schlumberger temperature, natural gamma ray, density, porosity, velocity, resistivity, and caliper tools in various combinations (Table 2). In addition, the uppermost sediments were logged through the pipe using the natural gamma ray and temperature tools. The results of this experiment, together with those of the Oblique Seismic Experiment in the same hole (Stephen et al., this volume) and of

\footnotetext{
${ }^{1}$ Contribution of the Départment Scientifique du Centre Oceanologique de Bretagne.
}

laboratory studies of the physical properties of the core material (Site 417 Report; Christensen et al.; Hamano et al.; Johnson; all, this volume) represent the most comprehensive body of geophysical data in existence on the in-situ properties of the oceanic basement and present an unprecedented opportunity to study the physical state of the upper levels of the crust (Salisbury et al., Synthesis Chapter, this volume).

\section{EQUIPMENT USED, OPERATIONS, AND LIMITATIONS}

After allowing the hole to equilibrate for 34 hours, the first logging tool to be run was a high-resolution temperature (HRT) tool designed to provide a temperature profile of the hole. Because of a sediment bridge at 46 meters subbottom, the main objective of the log was not accomplished. Nonetheless, a continuous recording was obtained of the temperature inside the pipe throughout the water column and within the uppermost sediments; 2 meters were logged open-hole (Figure 3 ). Although the thermistor wire in the tool was not calibrated, the water temperature near the mudline $\left(2.41^{\circ} \mathrm{C}\right)$ is reasonable; the conductive heat flow (1.1/ $\left.\mu \mathrm{cal} / \mathrm{cm}^{2} \mathrm{~s}\right)$ derived from the linear temperature gradient observed between 20 and 35 meters sub-bottom $(5.4 \times$ $10^{-2} \mathrm{C} / \mathrm{m}$ ) and the mean thermal conductivity of the sediments at the site $\left(2 \times 10^{-3} \mathrm{cal} / \mathrm{cm} \mathrm{s} \mathrm{C}^{\circ}\right.$; Site 417 Report, this volume) is identical to the regional heat flow in this part of the Atlantic (Lee and Uyeda, 1965).

The second set of logging tools to be run consisted of a borehole compensated velocity (BHC) tool in combination with a natural gamma ray (GR) tool and a 3-arm caliper designed to measure the borehole diameter.

The velocity tool consists of two compressional wave transducers and two pairs of receivers spaced approximately two feet apart. The interval transit time is measured by transmitting first to one pair of receivers and then to the other and averaging the difference in travel time between receivers for each pair. Since the geometry of the tool is analogous to that of a reversed refraction line, the data are corrected for variations in borehole diameter and for the tilt of the sonde. Since the borehole effect is thus minimized, the data are considered to be of high quality. It must be kept in mind, however, that the measured velocities can only be numerically correct for units thicker than the spacing of the receivers (i.e., $2 \mathrm{ft}$ ), and that since the signal associated with the first arrival only penetrates a few centimeters into the formation, the velocities are affected (decreased) by rugosity and formation damage. 
TABLE 1

Deep Basement Penetration Sites in the Atlantic

\begin{tabular}{|c|c|c|c|c|c|c|}
\hline Leg & Hole & Location & $\begin{array}{c}\text { Basement } \\
\text { Penetration }(\mathrm{m})\end{array}$ & $\begin{array}{l}\text { Recovery in } \\
\text { Basement (\%) }\end{array}$ & $\begin{array}{c}\text { Age } \\
\text { (m.y.B.P.) }\end{array}$ & Reference \\
\hline 37 & $332 \mathrm{~A}$ & $36^{\circ} 52.72^{\prime} \mathrm{N}, 33^{\circ} 38.46^{\prime} \mathrm{W}$ & 230 & 10 & 3.5 & $\begin{array}{l}\text { Site } 322 \text { Report in } \\
\text { Aumento, Melson, et al., } 1977\end{array}$ \\
\hline 37 & $332 \mathrm{~B}$ & $36^{\circ} 52.72^{\prime} \mathrm{N}, 33^{\circ} 38.46^{\prime} \mathrm{W}$ & 589 & 21 & 3.5 & $\begin{array}{l}\text { Site } 332 \text { Report in } \\
\text { Aumento, Melson, et al., } 1977\end{array}$ \\
\hline 37 & $333 \mathrm{~A}$ & $36^{\circ} 50.45^{\prime} \mathrm{N}, 33^{\circ} 40.05^{\prime} \mathrm{W}$ & 300 & 8 & 3.5 & $\begin{array}{l}\text { Site } 333 \text { Report in } \\
\text { Aumento, Melson, et al., } 1977\end{array}$ \\
\hline 45 & $395 \mathrm{~A}$ & $22^{\circ} 45.35^{\prime} \mathrm{N}, 46^{\circ} 04.90^{\prime} \mathrm{W}$ & 580 & 18 & 7 & $\begin{array}{l}\text { Site } 395 \text { Report in } \\
\text { Melson, Rabinowitz, et al., } 1979\end{array}$ \\
\hline 46 & $396 \mathrm{~B}$ & $22^{\circ} 59.14^{\prime} \mathrm{N}, 43^{\circ} 30.90^{\prime} \mathrm{W}$ & 256 & 23 & 10 & $\begin{array}{l}\text { Site } 396 \text { Report in } \\
\text { Dmitriev, Heirtzler, et al., } 1979\end{array}$ \\
\hline 49 & 409 & $62^{\circ} 36.98^{\prime} \mathrm{N}, 25^{\circ} 57.17^{\prime} \mathrm{W}$ & 240 & 24 & 2.3 & $\begin{array}{l}\text { Site } 409 \text { Report in } \\
\text { Cann, Luyendyk, et al., } 1979\end{array}$ \\
\hline $\begin{array}{l}51-53 \\
51-53\end{array}$ & $\begin{array}{l}417 \mathrm{~A} \\
417 \mathrm{D}\end{array}$ & $\begin{array}{l}25^{\circ} 06.63^{\prime} \mathrm{N}, 68^{\circ} 02.48^{\prime} \mathrm{W} \\
25^{\circ} 06.69^{\prime} \mathrm{N}, 68^{\circ} 02.82^{\prime} \mathrm{W}\end{array}$ & $\begin{array}{l}209 \\
366\end{array}$ & $\begin{array}{l}61 \\
72\end{array}$ & $\begin{array}{l}106 \\
106\end{array}$ & $\begin{array}{l}\text { Site } 417 \text { Report, this volume } \\
\text { Site } 417 \text { Report, this volume }\end{array}$ \\
\hline $51-53$ & $418 \mathrm{~A}$ & $25^{\circ} 02.10^{\prime} \mathrm{N}, 68^{\circ} 03.44^{\prime} \mathrm{W}$ & 544 & 72 & 106 & Site 418 Report, this volume \\
\hline
\end{tabular}

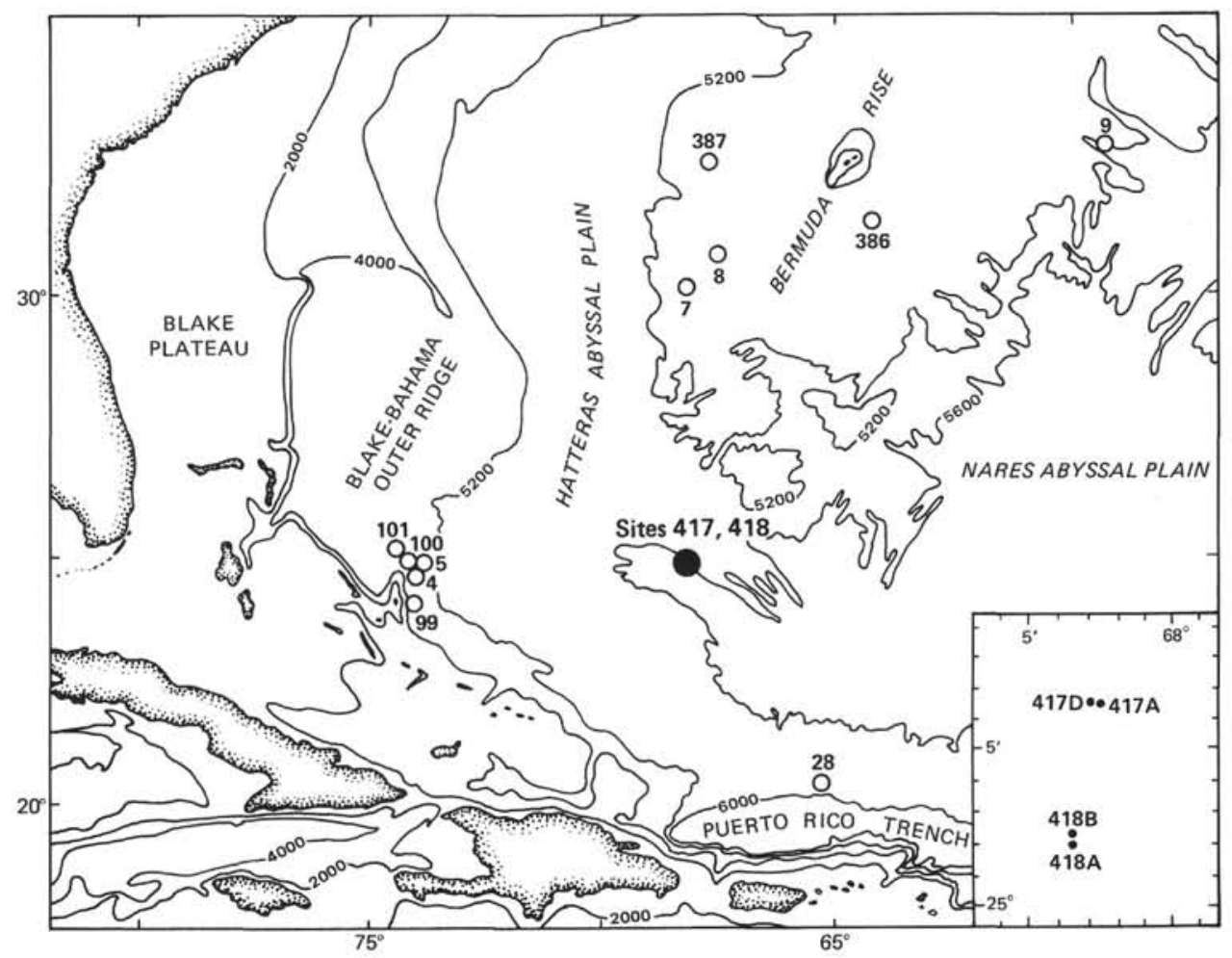

Figure 1. Location of Sites 417 and 418. Inset shows location of Hole 417D.

The GR tool measures the total natural gamma radiation reaching the tool from the formation. Since the average penetration of gamma rays is about one foot in sediments and 6 inches in basalt, the tool is only sensitive to gamma radiation derived from its immediate surroundings. Thus, zones of high gamma ray activity may be used as depth markers for correlation between logging runs. Although all three natural gamma logs obtained in the hole could be used for correlation, only the log run in combination with the velocity tool will be considered here. Since the tool used was non-spectral, no distinction can be made between radiation arising from the decay of $\mathrm{K}^{40}$ and the elements of the uranium-thorium series.

The caliper tool consisted of a 3-arm leaf spring, the dimensions of which are mechanically monitored in order to measure the borehole diameter as a function of depth. Unfortunately, the signal lead broke after an initial diameter measurement of 10 inches at the base of the hole.

The third set of logging tools to be run consisted of a compensated formation density (FDC) tool, a compensated neutron porosity log (CNL), and the GR tool discussed above. 


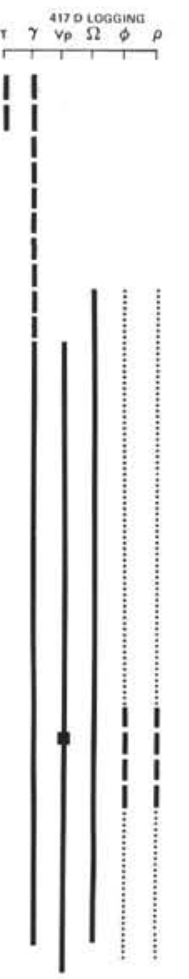

4170
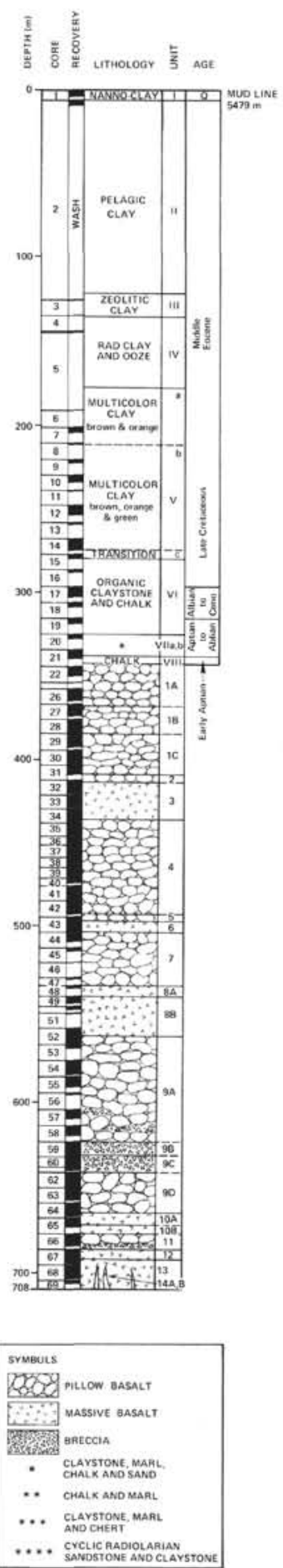

Figure 2. Logging intervals and data quality versus depth and lithology in Hole $417 \mathrm{D}$.
The density tool consists of a directional gamma ray source and two directional detectors spaced along the tool at different distances from the source. The emitted gamma rays lose their energy to electrons in the formation by Compton scattering; the scattered gamma rays which reach the two detectors are counted as a measure of the electron density of the formation and thus, the bulk density of the formation within one foot or less of the source. Although the effects of mudcake and wall rugosity can be partially corrected through the use of two detectors, the tool must be pressed firmly against the wall of the hole. This condition was met during a scaling run between 320 and 369 meters sub-bottom which straddled the basalt-sediment contact. In lowering the tool for the main run, however, the excentralizer broke and rendered subsequent measurements useless.

The porosity tool used consists of an Am-Be neutron source and two thermal neutron detectors spaced at increasing distances along the tool from the source. High energy neutrons emitted by the source lose their energy through collisions with particles in the formation. Since the energy loss is greatest for collisions between particles of equal mass, the number of low energy neutrons reaching the detectors is related to the hydrogen (and to a lesser extent, the boron and chlorine) content of the formation within one foot or less of the sonde. Since the hydrogen resides largely in water, the neutron tool provides a measure of the water content or porosity of the formation. As with the density tool, the effects of the borehole are greatly reduced through the use of two detectors. Although the tool is non-directional, it should be excentralized for best results since a standoff of as little as $2 \mathrm{~cm}$ can give an apparent increase in porosity of 5 per cent. Thus, the porosity results obtained for the 320-to-369-meter scaling run are considered reliable, while those obtained after failure of the excentralizer are considered poor except for several intervals in which the tool swung against the side of the hole.

The final set of logging tools consisted of a combined Dual Induction-Laterolog 8 (DIL) electrical resistivity tool and the GR tool. The resistivity tool consists of two induction tools which, respectively, investigate 1.5 meters (ILM) and 2.5 meters (ILD) into the formation with a vertical resolution of 1.5 meters, and a focused electrode or Laterolog 8 (LL8) tool which investigates to a depth of about 1 meter with a vertical resolution of 0.3 meter (Schlumberger, Ltd., 1972). The two induction tools measure the conductivity of the formation by monitoring the AC magnetic field associated with a Foucault current loop induced in the formation around the tool by an AC coil in the tool. The Laterolog 8 tool, on the other hand, measures the formation resistivity by transmitting a constant current into the formation in the form of a horizontal sheet and monitoring the potential drop between an electrode in the tool and one at the surface, as a function of depth. Although no centralizer was used, the resistivity data, with the exception of that obtained by the ILM tool, is of high quality because the tools are relatively insensitive to borehole effects (the depth of investigation greatly exceeds the diameter of the hole). 
TABLE 2

Hole 417D Geophysical Logging Runs

\begin{tabular}{|c|c|c|c|}
\hline Run & Tools & $\begin{array}{l}\text { Depth Interval } \\
\text { (m sub-bottom) }\end{array}$ & Remarks \\
\hline 1 & High Resolution Temperature (HRT) & $\begin{array}{r}0-44 \\
44-46\end{array}$ & $\begin{array}{l}\text { Through pipe } \\
\text { Open hole; terminated by caving }\end{array}$ \\
\hline 2 & $\begin{array}{l}\text { Borehole Compensated Velocity (BHC) } \\
\text { Natural Gamma Ray }\end{array}$ & $\begin{array}{r}144-445 \\
0-144 \\
144-445\end{array}$ & $\begin{array}{l}\text { Open hole } \\
\text { Through pipe } \\
\text { Open hole }\end{array}$ \\
\hline & Caliper & - & Signal lead broken, spot readings only \\
\hline 3 & $\begin{array}{l}\text { Gamma Ray Density } \\
\text { Neutron Porosity } \\
\text { Natural Gamma Ray }\end{array}$ & $\begin{array}{l}320-369 \\
114-443 \\
320-369 \\
114-443 \\
114-443\end{array}$ & $\begin{array}{l}\text { Open hole } \\
\text { Open hole; excentralizer broken; data not shown } \\
\text { Open hole } \\
\text { Open hole; excentralizer broken } \\
\text { Open hole }\end{array}$ \\
\hline 4 & $\begin{array}{l}\text { Electrical Resistivity } \\
\text { (ILM, ILD, LL8) } \\
\text { Natural Gamma Ray }\end{array}$ & $\begin{array}{l}117-434 \\
117-434\end{array}$ & $\begin{array}{l}\text { Open hole; no centralizer } \\
\text { Open hole }\end{array}$ \\
\hline
\end{tabular}

\section{DATA}

Since many of the properties measured by logging are sensitive to temperature, pressure, the hole diameter, and the properties of the fluid in the hole, the data obtained above have been corrected to in-situ conditions. These corrections assume the following: a $10^{\prime \prime}$ hole filled with sea water, an average hydrostatic confining pressure of 0.6 kbar, a temperature of $2.4^{\circ} \mathrm{C}$ at the mudline, and a temperature gradient of $5.4 \times 10^{-2} \mathrm{C} \% \mathrm{~m}$ in the sediments and $2.2 \times 10^{-2} \mathrm{C}^{\circ} / \mathrm{m}$ in the basalts, which corresponds to a uniform heat flow of $1.1 \mu \mathrm{cal} / \mathrm{cm}^{2} \mathrm{~s}$. Figure 4 (back pocket, this volume) presents the corrected logging data for Hole 417D, together with the lithology of the drilled section (Site 417 Report, this volume). Also shown are modal analyses based on X-ray diffraction studies of the sediments (Müller and Mann, this volume) and on visual inspection in the basement. Since the upper 200 meters of Hole 417D were only spot cored, the upper levels of the column are represented by data from Hole 417A.

\section{DISCUSSION}

\section{Sediments}

With the exception of a small number of thin claystone and chert layers recovered near the base of the section, the sediments recovered from Hole 417D (and presumably, the walls of the hole) were strongly disturbed by drilling. Since most of the logging tools only investigate a few inches into the formation, the logging data for the sediments cannot be regarded as representative of the formation or as susceptible to correction.

Nonetheless, a qualitative interpretation of the logging data remains feasible. As can be seen in Figure 4, the sediment column (Site 417 Report, this volume) consists of approximately 280 meters of unconsolidated to poorly consolidated clay (Units I through V) underlain by organic claystone and chalk between 280 and 325 meters subbottom (Unit VI), cyclic radiolarian sandstone and claystone between 325 and 340 meters (Unit VII), and chalk between 340 and 343 meters sub-bottom (Unit VIII). While the modal analyses tend to confirm these lithologic designations, they suggest different thicknesses for the lower three units, namely that Unit VI (on the basis of carbonate content) extends from 280 to 305 meters, Unit VII (on the basis of quartz) extends from 305 to about 330 meters, and Unit VIII (carbonate) extends from about 330 to 343 meters sub-bottom.

Aside from the natural gamma log, which is often insensitive to either physical properties or bulk mineralogy, the downhole logs in Hole 417D are broadly consistent with the lithologic column described above, particularly that based on modal analyses. Within the unconsolidated to poorly consolidated clays of Units I through V, the logs show almost no character. Below the clay to claystone transition, however, the porosities decrease throughout most of Units VI and VII to levels lower than the CNL tool saturation level of 70 per cent, with the lowest porosities and the highest velocities and densities being observed in zones containing thin layers of limestone (Unit VI) and chert (Unit VII) interbedded with mixed-layer clays. The high porosities and low velocities and densities at the base of the sediment section are associated with drilling disturbance and caving in unconsolidated chalk near the sediment-basement contact.

Interpretation of the natural gamma log is less obvious. The peaks in the log show no correlation with either bulk mineralogy, illite content (Müller, this volume), or potassium content (Donnelly, this volume). There is, however, a possible correlation with concentrations of fish debris in the black clays near the base of the section, suggesting that the natural gamma peaks in Units VI and VIII are due to uranium enrichment. Since such concentrations were not recovered in the upper levels of the section, the natural gamma peaks in Units IV and V remain unexplained. Finally, it should be noted that the remainder of the hole was logged through the pipe; thus the natural gamma fluctuations observed above Unit IV are due in part to variations in pipe thickness and hole diameter.

\section{Basalts}

The downhole logs for the basement section of Hole 417D, like those in the overlying sediments, are consistent 


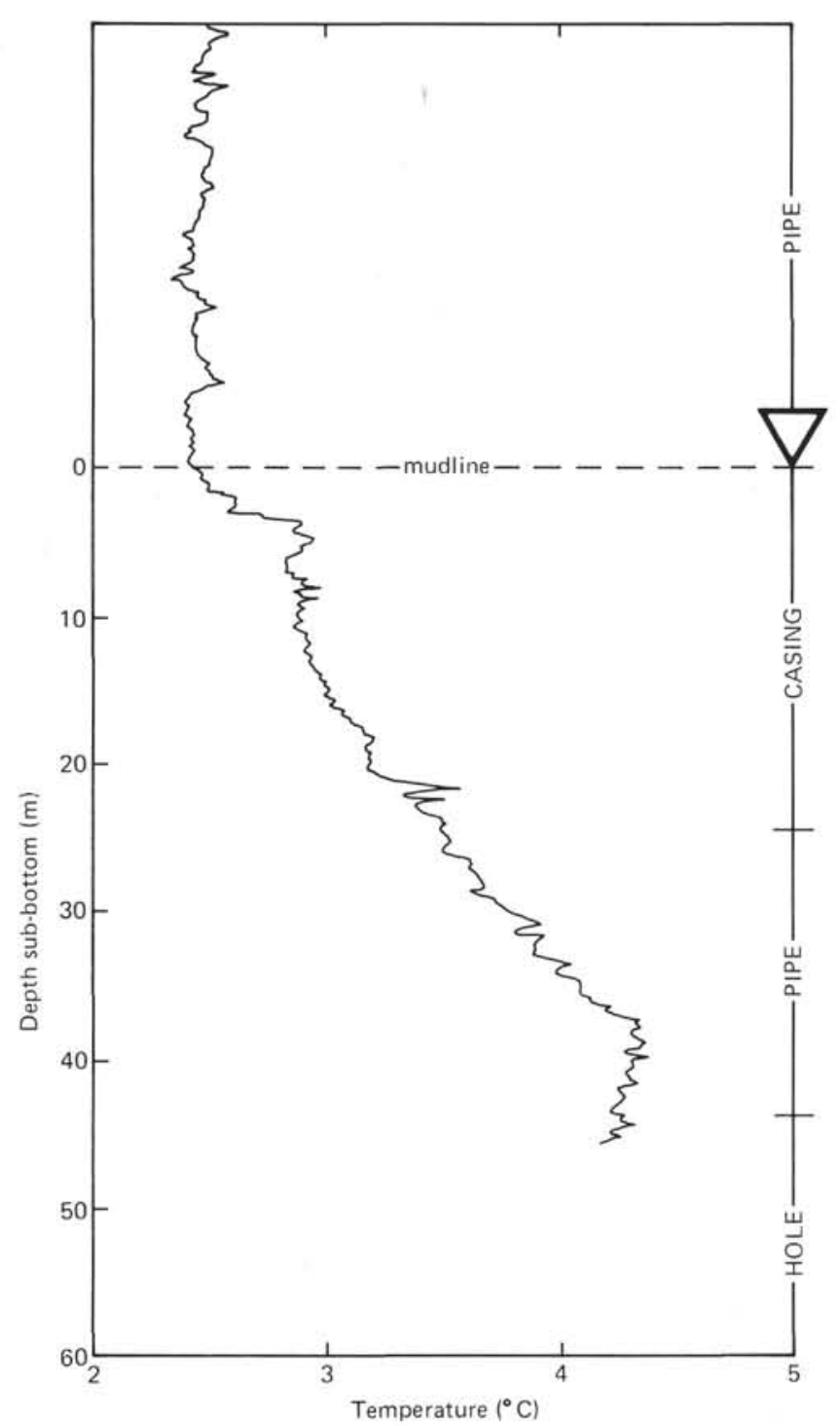

Figure 3. High resolution temperature data versus depth in sediments in Hole 417D. The change in temperature behavior below 37 meters is attributed to sediments lodged on the thermistor wire.

with the lithology observed in the hole. As can be seen in Figure 4, the section consists of 71 meters of pillow basalt containing minor breccia and interpillow fillings of calcite and clay (Units 1 and 2) underlain by a massive basalt unit between 413 and 435 meters sub-bottom (Unit 3) and a pillow basalt with clay fillings (Unit 4 ) between 435 meters and the base of the logged interval at 445 meters. Although the basalts are all plagioclase-phyric with subordinate phenocrysts of olivine \pm clinopyroxene and all have essentially the same chemical compositions (Site 417 Report, this volume), most of the units and subdivisions delineated on the basis of lithology can also be noted on the basis of logging. The massive basalts of Unit 3 , for example, have distinctly higher and more uniform velocities than the pillow basalts of Units 1,2, and 4 and individual flows within the pillow basalts can often be distinguished by thin zones of low velocity and high porosity associated with altered breccias along their contacts.
The most important application of the basement logs, however, is the determination of the in-situ physical properties of the crust for comparison with geophysical data obtained from the surface. Since there appears to be no formation damage (the Laterolog 8 and ILD data coincide throughout most of basement), this can be accomplished provided the logging data can be used quantitatively.

Although there may be a small systematic error in data obtained using the Schlumberger velocity tool (Wang and Simmons, 1978), the compressional wave velocity data obtained in Hole 417D is considered to be of high quality since the tool functioned properly throughout the run. As noted above, however, the density and porosity data are suspect because of a broken excentralizer with the exception, perhaps, of the data logged between 320 and 369 meters. The quality of the density data in this interval may be tested by plotting the velocity and density data obtained by logging against data obtained in the laboratory as a function of pressure for rock samples from the same interval (Figure 5). If both logging tools were functioning properly, the logging data should simply plot as an extension of the laboratory data obtained at pressures appropriate to in-situ conditions (dotted line at $0.1 \mathrm{kbar}$ ). As can be seen in Figure 5, the logging data plot well to the left of the laboratory data, suggesting that the density tool was reading low by about $0.1 \mathrm{~g} / \mathrm{cm}^{3}$ even during the scaling run.

If the porosity of rocks from the logged interval is known from laboratory studies, the error of the porosity tool can now be determined by plotting the density and porosity data obtained by logging against that obtained in the laboratory as in Figure 6. If the tools are operating properly, the logging data should plot along the same grain density solution as that observed in the laboratory (dotted line at 2.95 $\left.\mathrm{g} / \mathrm{cm}^{3}\right)$. After correcting the density data by $+0.1 \mathrm{~g} / \mathrm{cm}^{3}$ as suggested above, the logging data are observed to plot above the laboratory grain density solution, suggesting that the porosity tool was reading high by approximately 8 per cent during the scaling run.

Normally, the accuracy of such corrections can only be estimated from internal consistency checks between logs. In the present case, however, the formation porosity of Unit 3 can be independently estimated from laboratory measurements; since the massive basalts of the unit appear to be relatively crack-free (the recovery was in the form of continuous pieces up to $0.5 \mathrm{~m}$ long), formation porosities and porosities determined in the laboratory from hand samples should be roughly equivalent. A comparison of the minimum values obtained by logging in Unit 3 and the porosities determined in the laboratory for samples from the same interval (10 and $3 \%$, respectively) suggests that the porosity tool was reading high by about 7 per cent, a value in excellent agreement with the estimate cited above.

It is interesting to note in Figure 6, that even after correction, the porosities obtained by logging are approximately 5 per cent higher than the laboratory data, while the densities are lower by about $0.1 \mathrm{~g} / \mathrm{cm}^{3}$, suggesting that the formation contains about 5 per cent cracks by volume. Visual checks of the core confirm that cracks are common throughout most of the section, particularly in the pillow basalts (Johnson, "Crack distribution" chapter, this volume). An in-situ check can be performed using the porosity dependent logging data by plotting values of $\mathrm{M}$ versus $\mathrm{N}$ for the scaling 


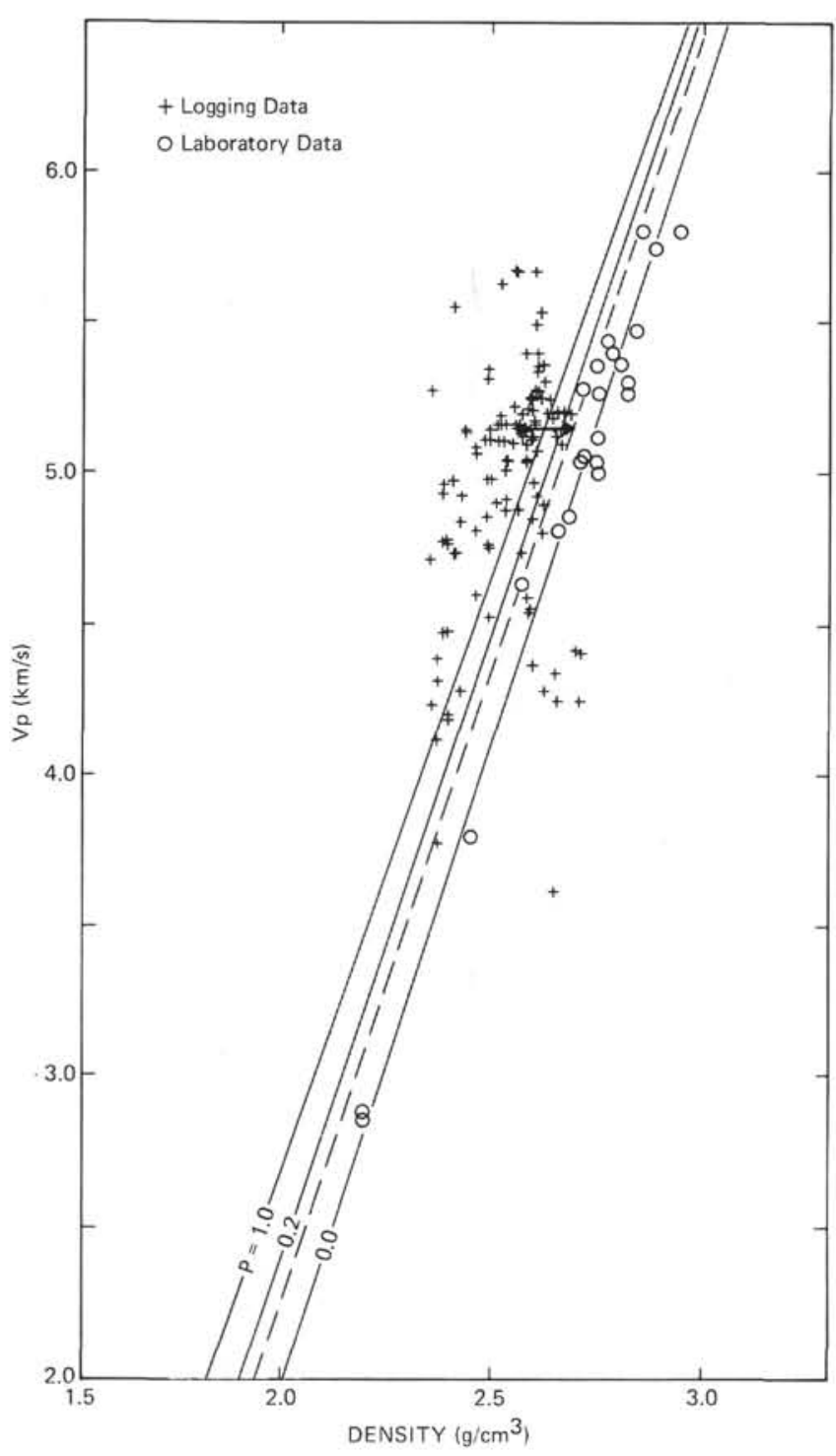

Figure 5. Compressional wave velocity versus density for basement logs (crosses) obtained between 343 and 369 meters and for laboratory data (circles) obtained at atmospheric pressure for rock samples from Hole $417 D$ (Site 417 Report, this volume). Also shown are leastsquares solutions to laboratory data at elevated pressures from Christensen et al. (this volume); dotted line represents solution at effective in situ confining pressure of 0.1 kbar. Arrow represents density correction to logging data of $+0.1 \mathrm{~g} / \mathrm{cm}^{3}$.

run, where $\mathrm{M}$ and $\mathrm{N}$ are lithology-dependent quantities given by

$$
\mathrm{M}=\frac{\mathrm{t}_{\mathrm{f}}-\mathrm{t}}{\rho_{\mathrm{b}}-\rho_{\mathrm{f}}}, \quad \mathrm{N}=\frac{(\phi \mathrm{N})_{\mathrm{f}}-\phi_{\mathrm{N}}}{\rho_{\mathrm{b}}-\rho_{\mathrm{f}}},
$$

where tf is the fluid transit time (189 $\mu \mathrm{s} / \mathrm{ft}), \mathrm{t}$ is the measured transit time from the $\log , \rho_{\mathrm{b}}$ is the bulk density from the density $\log , \rho \mathrm{f}$ is the density of the pore fluid (1.036 $\mathrm{g} / \mathrm{cc}),\left(\phi_{\mathrm{N}}\right) \mathrm{f}$ is the "fluid porosity" $(1.00)$, and $\phi_{\mathrm{N}}$ is the porosity from the $\log$. Since velocities are much more

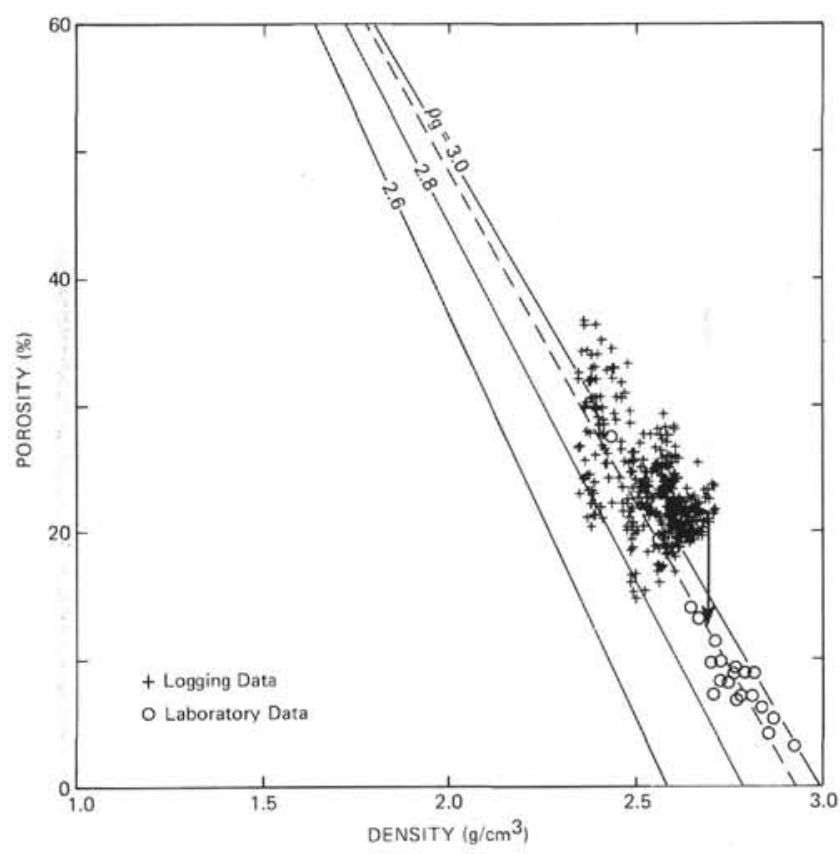

Figure 6. Density versus porosity for basement logs (crosses) obtained between 343 and 369 meters and for laboratory data (circles) obtained for rock samples from Hole 417D (Site 417 Report, this volume). Also shown are density-porosity control lines as a function of grain density; dotted line represents solution at observed grain density of $2.95 \mathrm{~g} / \mathrm{cm}^{3}$. Arrows represent density and porosity corrections to logging data of $+0.1 \mathrm{~g} / \mathrm{cm}^{3}$ and $-8 \%$, respectively.

strongly influenced by the presence of cracks than porosities are, the vertical pattern in Figure 7 confirms that the basement interval between 343 and 369 meters is laced with open fractures.

An estimate of the degree of interconnection of the cracks noted above can be made by plotting the formation factor and porosity data obtained for the scaling run and determining the best fit to the data using Archie's law (1942),

$$
\mathrm{F}=\mathrm{C} \phi^{-\mathrm{m}}
$$

where the formation resistivity factor,

$$
\mathrm{F}=\frac{\mathrm{R}_{\mathrm{O}}}{\mathrm{R}_{\mathrm{w}}},
$$

where $\mathrm{C}$ is a constant, $\phi$ is the porosity, $\mathrm{m}$ is a measure of the interconnection of pores, $R_{0}$ is the resistivity of the formation, and $R_{w}$ is the in-situ resistivity of the pore water $\left(0.25 \Omega\right.$-m for sea water at $\left.20^{\circ} \mathrm{C}\right)$. If the logging data are corrected for the 8 per cent porosity error discussed above, it plots as an extension of the laboratory formation factor and porosity data for Holes 417D and 418A. As indicated in Figure 8 , the exponent, $\mathrm{m}$, in the best fit to the corrected logging data is less than 2.0 which indicates that the pores and cracks in the uppermost levels of the basement in Hole 417D are uncemented (i.e., interconnected) and that the permeability is high. 


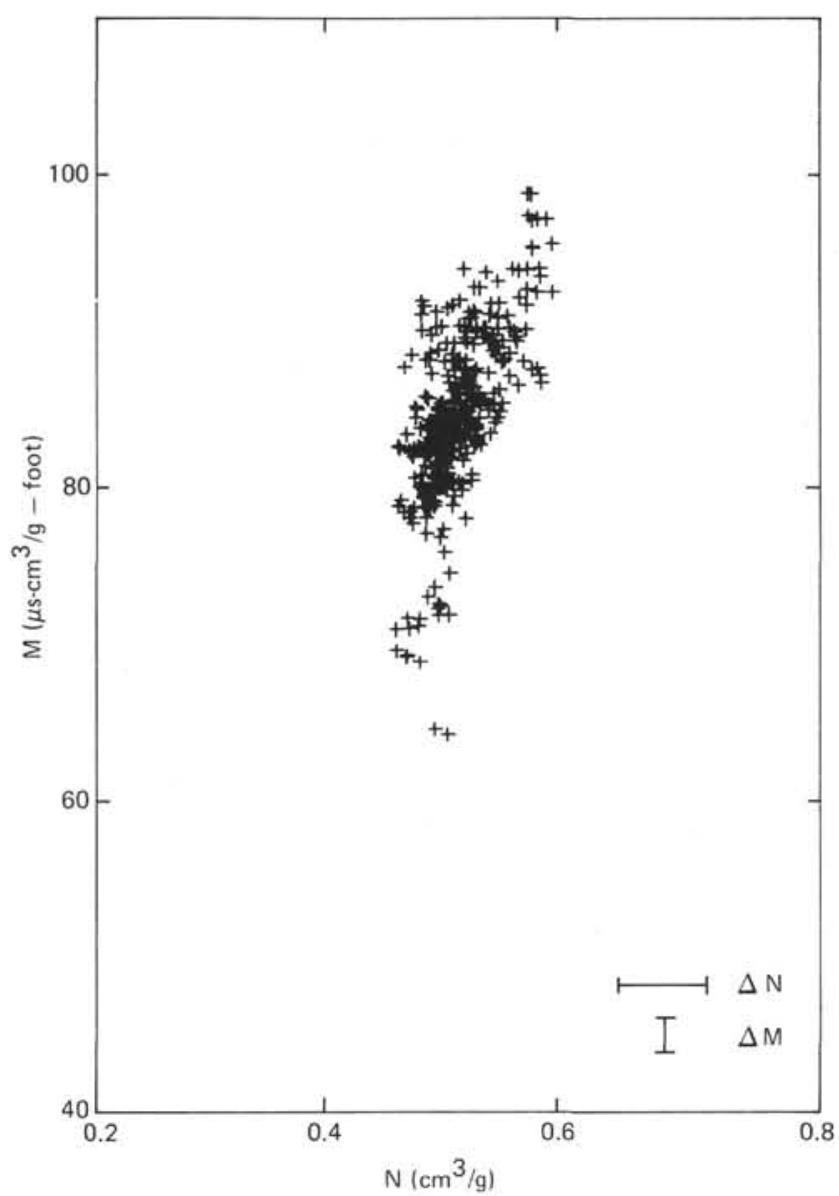

Figure 7. $M$ versus $N$ for basement logs obtained between 343 and 369 meters. Vertical pattern indicates presence of cracks. $\Delta N$ bracket indicates range in $N$ associated with porosity error of $8 \% ; \Delta M$ bracket indicates range for density error of $0.1 \mathrm{~g} / \mathrm{cm}^{3}$.

\section{CONCLUSIONS}

Although the logging operation in Hole 417D was beset with operational difficulties associated with logging at sea from a floating platform, all of the tools, with the exception of the temperature log, were successfully run in the uppermost levels of the basement and three (the velocity, resistivity, and GR tools) were run successfully throughout the entire section. The logs thus obtained represent the only logs run to date in old oceanic crust and one of the few direct measurements of in-situ physical properties in the basement. From the above analysis, a number of important conclusions can be drawn concerning the physical state of old oceanic crust:

1) Correlation with lithology: The downhole logs obtained in Hole 417D may be used as an aid in the determination of lithology and the location of boundaries between units in zones of low recovery. In the sediments of Hole $417 \mathrm{D}$, for example, the logs are consistent with the lithologic units defined on the basis of modal analysis, while in the underlying basement, the pillow basalts can be distinguished from massive basalts through comparison of the velocity and porosity logs. Furthermore, the boundaries between units in the basalts can often be distinguished by a sharp decrease in density, resistivity, and compressional wave velocity, and a marked increase in porosity and natural gamma ray activity associated with brecciation, alteration, and potassium enrichment along flow contacts (Donnelly et al., this volume).

2) Correlation with reflection records: The logs obtained in Hole 417D may also be used as an aid in interpreting seismic reflection records for the site. The claystone to radiolarian sand and claystone transition at 305 meters and the sediment/basement contact at 343 meters sub-bottom, for example, should be prominent reflectors due to increases in acoustic impedance. Interestingly, the low velocity zones associated with breccias within the basement should also be reflectors, were equipment available for their detection.

3) Temperature: The temperature in Hole 417D increases with depth in the sediments at a rate of $5.4 \times$ $10^{-2} \mathrm{C} / \mathrm{m}$ from a low of $2.4^{\circ} \mathrm{C}$ at the mudline. This suggests that the uppermost levels of the basement are at room temperature.

4) Resistivity: The electrical resistivity of the uppermost levels of the basement in Hole 417D ranges between 30 and $80 \Omega$-meters, with lower values observed in breccias and higher values (up to $200 \Omega$-m), with lower values observed in massive basalts. Since the resistivity of dry basalt at room temperature ranges from $10^{3}$ to $10^{6} \Omega$-meters (Hyndman and Hall, 1974), the basement in Hole 417D is clearly saturated with sea water. Finally, the presence of steep or subvertical fractures is inferred in several basement intervals from the fact that RILD $>$ RLL8.

5) Velocity: The compressional wave velocities in the uppermost levels of the basement in Hole 417D range for the most part between 4.7 and $5.3 \mathrm{~km} / \mathrm{s}$ with lower velocities displayed in breccias and velocities as high as 5.8 $\mathrm{km} / \mathrm{s}$ displayed in the massive basalts. The formation velocity derived from integrated transit time data for the entire logged basement interval between 343 and 445 meters subbottom is $4.8 \mathrm{~km} / \mathrm{s}$, a value consistent with those reported for Layer 2B by Houtz and Ewing (1976). This value is considerably higher than the Layer $2 \mathrm{~A}$ formation velocity of $3.6 \mathrm{~km} / \mathrm{s}$ reported by Kirkpatrick (1979) for the basement section drilled in Hole 396B in young crust along the same flow line and supports the observation that Layer $2 \mathrm{~A}$ does not commonly persist in the Atlantic beyond the 60-m.y. isochron. Examination of the core material from Hole 417D clearly indicates that the increase in formation velocity in the upper levels of Layer 2 with age is due to the infilling of cracks and interpillow voids by the products of low temperature alteration.

6) Porosity, density, and permeability: Despite such infilling, the porosity of the upper levels of the basement in old crust is non-trivial. The total porosity of the logged basement interval in Hole 417D averages 13 per cent, of which approximately 8 per cent is due to grain boundary porosity in basalt, and 5 per cent is due to open cracks filled with standing water. These cracks decrease the formation density by about $0.05 \mathrm{~g} / \mathrm{cm}^{3}$ (from laboratory values) to an observed average of $2.70 \mathrm{~g} / \mathrm{cm}^{3}$.

The most important influence of such cracks, however, is upon formation permeability. The cracks in Hole 417D, despite their age and partial infilling, are interconnected, 


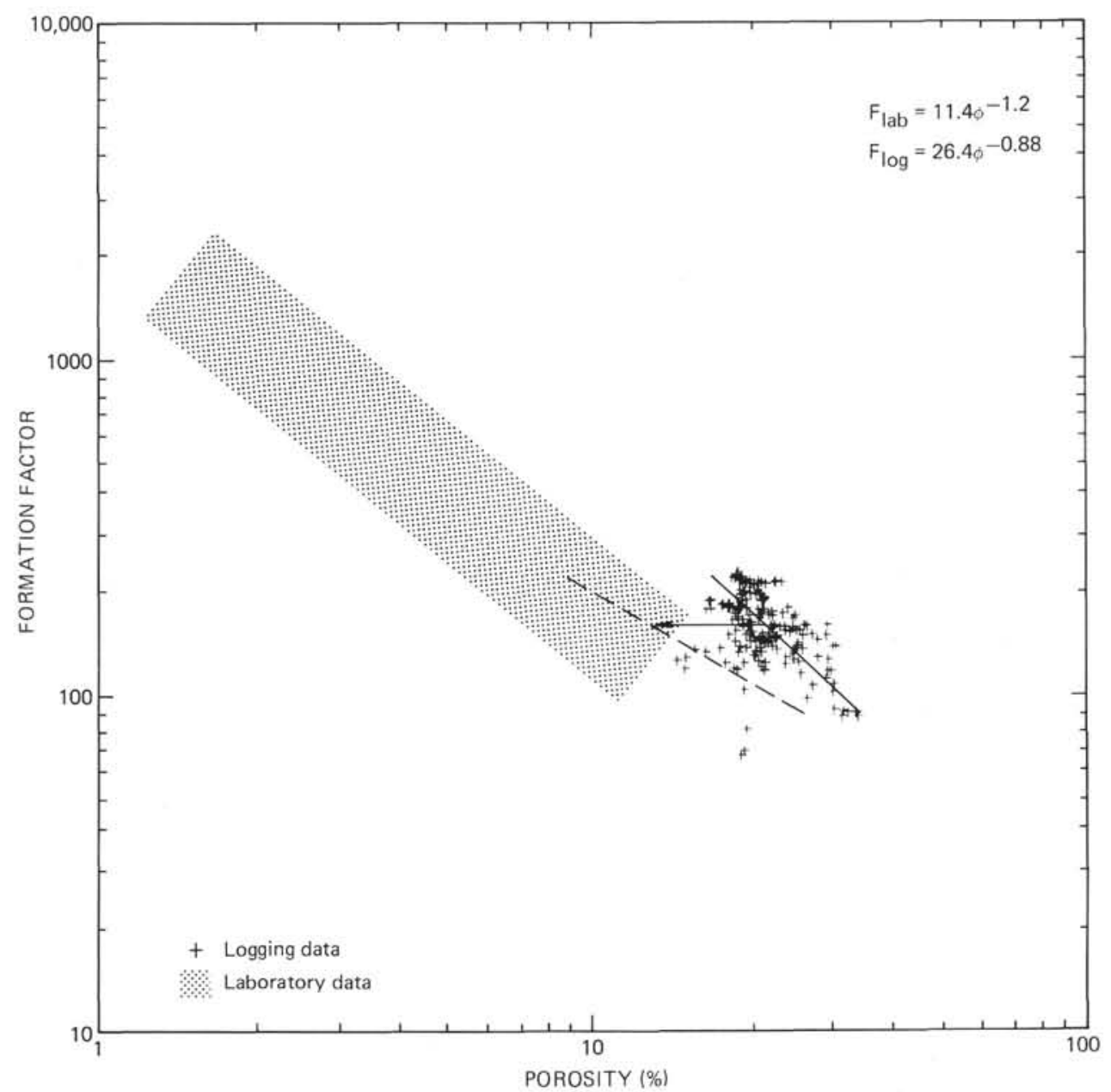

Figure 8. Formation factor versus porosity for basement logs obtained between 343 and 369 meters and for laboratory data obtained from rock samples from Holes $417 \mathrm{~A}$ and $418 A$ (Hamano, this volume). Dotted line represents best fit to logging data after $-8 \%$ correction (arrow). Solutions to laboratory and logging data are based on Archie's Law (see text).

which causes the formation to have an extremely high permeability (Johnson, "Permeability" chapter, this volume). This implies that convective heat transfer in old oceanic basement is limited by the availability of heat and the permeability of the overlying sediments and that the alteration of submarine basalts is only terminated by subduction.

\section{ACKNOWLEDGMENTS}

We wish to thank the Captain and crew of the Glomar Challenger for their assistance during the logging operation; Loic Beurdeley of Schlumberger, Ltd. for operating the logging tools; and Ron Jones, Jim Vohs, and Steve Bearman for their assistance in processing the data. We also wish to thank N.I. Christensen, Jim Kirkpatrick, and Gene Boyce for their many helpful suggestions during the course of this study.

\section{REFERENCES}

Archie, G.E., 1942. The electrical resistivity $\log$ as an aid in determining some reservoir characteristics, Pet. Tech., v. 5 .

Aumento, F., Melson, W.G., et al., 1977a. Site 332. In Aumento, F., Melson, W.G., et al., Initial Reports of the Deep Sea
Drilling Project, v. 37: Washington (U.S. Government Printing Office), p. 15-200. , 1977b. Site 333. In Aumento, F., Melson, W.G., et al., Initial Reports of the Deep Sea Drilling Project, v. 37: Washington (U.S. Government Printing Office), p. 201-238.

Cann, J.R., Luyendyk, B., et al., Site 409, 1979. In Cann, J.R., Luyendyk, B., et al., Initial Reports of the Deep Sea Drilling Project, v. 49: Washington (U.S. Government Printing Office), p. 161-226.

Dmitriev, L., Heirtzler, J., et al., 1979. Holes 396A and 396B, 1979. In Dmitriev, L., Heirtzler, J., et al., Initial Reports of the Deep Sea Drilling Project, v. 46: Washington (U.S. Government Printing Office), p. 15-86.

Houtz, R. and Ewing, J., 1976. Upper crustal structure as a function of plate age, J. Geophys. Res., v. 81, p. 2490-2498.

Hyndman, R.D. and Ade-Hall, J.M., 1974. Electrical resistivity of basalts from DSDP Leg 26. In Davies, T.A., Luyendyk, B.P., et al., Initial Reports of the Deep Sea Drilling Project, v. 26: Washington (U.S. Government Printing Office), p. 505508.

Kirkpatrick, R.J., 1979. Results of downhole geophysical logging Hole 396B, DSDP Leg 46. In Dmitriev, L., Heirtzler, J., et 
al., Initial Reports of the Deep Sea Drilling Project, v. 46: Washington (U.S. Government Printing Office), p. 401-408.

Lee, W.H.K. and Uyeda, S., 1965. Review of heat flow data. In Lee, W.H.K. (Ed.), Terrestrial Heat Flow, Geophys. Mono. Ser., Washington (Am. Geophys. Union), p. 87-190.

Melson, W.G., Rabinowitz, P.D., et al., 1979. Site $395: 23^{\circ}$ N, Mid-Atlantic Ridge. In Melson, W.G., Rabinowitz, P.D., et al., Initial Reports of the Deep Sea Drilling Project, v. 45: Washington (U.S. Government Printing Office), p. 131-264. Schlumberger, Ltd., 1972. Log Interpretation, Volume 1 Principals, $113 \mathrm{p}$.

Wang, H.F. and Simmons, G., 1978. Microcracks in crystalline rocks from 5.2-km depth in the Michigan Basin, J. Geophys. Res., v. 83, p. 5849-5856. 